\title{
A Simple Pre-concentration Method for the Determination of Nickel(II) in Urine Samples Using UV-Vis Spectrophotometry and Flame Atomic Absorption Spectrometry Techniques
}

\author{
Ahmed Fadhil Khudhair ${ }^{1, *}$, Mouyed Khudhair Hassan ${ }^{2}$, Hasan F. Alesary ${ }^{1}$, and Ahmed S. Abbas ${ }^{3}$ \\ ${ }^{1}$ Department of Chemistry, College of Science, University of Kerbala, Karbala, Iraq \\ ${ }^{2}$ Oil Products Distribution Company (Kerbala), Ministry of Oil, Iraq \\ ${ }^{3}$ Department of Chemistry, College of Science, University of Babylon, Babylon, Iraq
}

\section{* Corresponding author:}

email:ahmmed.mutar@uokerbala.edu.iq

Received: May 21, 2018

Accepted: June 25, 2018

DOI: $10.22146 /$ ijc.35681

\begin{abstract}
The cloud point technique was effectively utilized for extraction and preconcentration of nickel(II) in urine samples before measurement by UV-Vis spectrophotometer and AAS techniques. The metal response to a para-aminophenol (PAP) reagent in a non-ionic surfactant Triton $X-114$ medium was to form the NiPAP complex. The adopted concentration for PAP, concentration of Triton X-114, $p H$ effect and water bath temperature, incubation time, salt effect, and interference effects were all optimized. The calibration curve was linear over the range of (0.0625-1.25) mg. $L^{-1}$ with a correlation coefficient $r^{2}$ of 0.9682 for the UV-Vis spectrophotometer at a $\lambda_{\max }$ of $629 \mathrm{~nm}$. The limit of detection was $0.005 \mathrm{mg} / \mathrm{L}$. The relative standard deviation for six replicates was $1.07 \%$. This method was applied successfully to determine copper (II) concentrations in 44 urine samples of occupational worker samples as determined by UV-Vis spectrophotometry and FAAS techniques.
\end{abstract}

Keywords: Ni(II); cloud point extraction; non-ionic surfactant; urine sample, $U V$ Vis spectrophotometer; FAAS

\section{- INTRODUCTION}

Estimating trace elements in biological samples is an important area of study to evaluate occupational and environmental exposure [1]. Nickel is considered to be moderately toxic compared to other elements. However, the inhalation of fumes containing nickel may lead to serious health problems [2]. Nickel has several industrial uses, such as its use in electroplating, ceramics, magnetic tapes, computer components as well as in the manufacture of arc-welding rods. Nickel is present in water, soil and the atmosphere as a result of industrial processes and improper disposal of industrial waste [3]. Nickel plays a role in the formation of certain enzymes such as the urease enzyme which is necessary for animals and plants. Considerable attention has been paid to the toxicity of nickel in low concentrations because nickel can cause an allergic reaction and certain nickel compounds may be carcinogenic [4]. Moreover, nickel can cause a disorder known as nickel-eczema [2]. The concentration range of nickel in urine is $0.27-3.68 \mathrm{ng} / \mathrm{mL}$ with a median value of $1.7 \mathrm{ng} / \mathrm{mL}$ [5]. There are commonly used analytical methods in which nickel concentrations have been determined, such as FAAS [6-10]. Inductively coupled plasma mass spectrometry (ICP-MS) [11-13], graphite furnace-atomic absorption spectrometry (GFAAS) [14], UV-VIS spectrometry [15-16], inductively coupled plasma optical emission spectrometry [17-18]. The cloud point extraction method has become an important method that is commonly used for pre-concentration and element estimation [19]. Cloud point extraction processes occur depending on the use the phase behavior of non-ionic surfactants in aqueous solutions, where micelles are formed, and the solution becomes cloudy when heating to a certain temperature. At higher temperatures, phase separation will occur [20]. The typical surfactants used in the CPE processes mostly 
include (1) anionic surfactants, such as sodium dodecyl sulphate (SDS). (2) Non-ionic surfactants, such as Triton X-100, Triton X-114. (3) Cationic surfactants, for example cetyl trimethyl ammonium bromide (CTAB). (4) Zwitterionic surfactants have one cationic center and one anionic part [21]. CPE is applied to determine trace element concentrations such as Fe(III) [22] and Se(II) [23].

The aim of this study was the development of a sensitive, selective and environmentally friendly spectro metric method of determination of $\mathrm{Ni}$ (II) concentration using para-aminophenol (PAP) as a complexing agent and cloud point extraction. A UV-Vis spectrophotometer was used as detection technique and the proposed method was applied to a number of samples. In the present work, the CPE method has been used for separation and preconcentration of nickel(II) after the formation of a complex with PAP, using Triton X-114 as the surfactant and then measurement by using a UV-VIS spectrophoto meter at $629 \mathrm{~nm}$ and FAAS techniques. The analytical conditions for the pre-concentration of nickel were investigated.

\section{- EXPERIMENTAL SECTION}

\section{Apparatus}

The $\mathrm{pH}$ of the solution was adjusted by using a WTW (model 720) $\mathrm{pH}$ meter with a combined glass electrode. A Hettich centrifuge (model EBA - 20, Germany) with $10 \mathrm{~mL}$ calibrated centrifuge tubes was used for phase separation at $3600 \mathrm{rpm}$ for $5 \mathrm{~min}$. A water bath (Lab companion BS-11 Shaking Water bath) with an excellent temperature control was used to accelerate CPE experiments. Micropipettes ((10-100) $\mu \mathrm{L}$ and (100-1000) $\mu \mathrm{L})$ were used to deliver accurate volumes. A Lab Line Super Mixer (model 129) Hitech Trader, U.S.A. was used to mix the solution. All absorption spectra were recorded on a Shimadzu double beam UV-VIS. spectrophotometer (UV-1800, Japan) equipped with deuterium and tungsten lamps and using $1 \mathrm{~cm}$ quartz cells $(0.5 \mathrm{~mL})$ for all measurements. The trace nickel was measured by using atomic absorption techniques (Atomic Absorption -AA7000- Shimadzu-Japan).

\section{Reagent and Solutions}

Solutions were prepared using analytical grade chemicals and deionized water. 1\%(w/v) of paraaminophenol (PAP) was prepared by dissolving $1 \mathrm{~g}$ PAP in (1-2) $\mathrm{mL}$ dimethylsulphoxide (DMSO) and then adding absolute ethanol to a $100 \mathrm{~mL}$ volumetric flask. Solutions of non-ionic surfactant Triton X-114 were prepared at a $20 \%(\mathrm{v} / \mathrm{v})$ concentration by diluting $20 \mathrm{~mL}$ of Triton X-114 to $100 \mathrm{~mL}$ (hot deionized water) in a volumetric flask. A stock solution of $1000 \mathrm{mg} / \mathrm{L}$ of $\mathrm{Ni}(\mathrm{II})$ was prepared by dissolving $0.3 \mathrm{~g} \mathrm{Ni}\left(\mathrm{NO}_{3}\right)_{2}$ in $100 \mathrm{~mL}$ deionized water.

\section{Sample Collection}

Urine samples were collected from people working in different professions such as dyeing, welding, casting alloys, and oil refineries, and then terminals to provide fuel and quality control within the oil sector. Urine samples were collected in a fresh polyethylene bottles $(120 \mathrm{~mL})$ and stored in a fridge at $(0-5){ }^{\circ} \mathrm{C}$ to keep the models from damage after that are initialized urine samples for subsequent operations.

\section{Urine Sample Digestion}

Digestion of urine samples was carried out via the following steps [24-25]. In a $100 \mathrm{~mL}$ beaker, $25 \mathrm{~mL}$ of urine sample was treated with a mixture of $5 \mathrm{~mL} \mathrm{H}_{2} \mathrm{O}_{2}$ and $2.5 \mathrm{~mL}$ of conc. $\mathrm{HNO}_{3}$, and placed on a hot plate. The samples were then heated until the dark color turned light. Then, the samples were heated until completely dry. $2.5 \mathrm{~mL}$ of conc. $\mathrm{HNO}_{3}$ was added to the resultant dark residue and reheated until dry; this step was repeated several times until white ashes were produced. These were dissolved in the final step using $2.5 \mathrm{~mL}$ of $3 \mathrm{M} \mathrm{HCl}$.

\section{Cloud Point Extraction Procedure}

CPE has been carried out according to the following aliquots of $10 \mathrm{~mL}$ of the working solution containing $0.5 \mathrm{ppm}$ of $\mathrm{Ni}(\mathrm{II}), 0.25 \mathrm{~mL}$ of $1 \%$ (w/v) PAP reagent and then left for $30 \mathrm{~min}$ to complete the reaction with $0.5 \mathrm{~mL}$ of $20 \%(\mathrm{v} / \mathrm{v})$ triton $\mathrm{X}-114$. The mixture was 


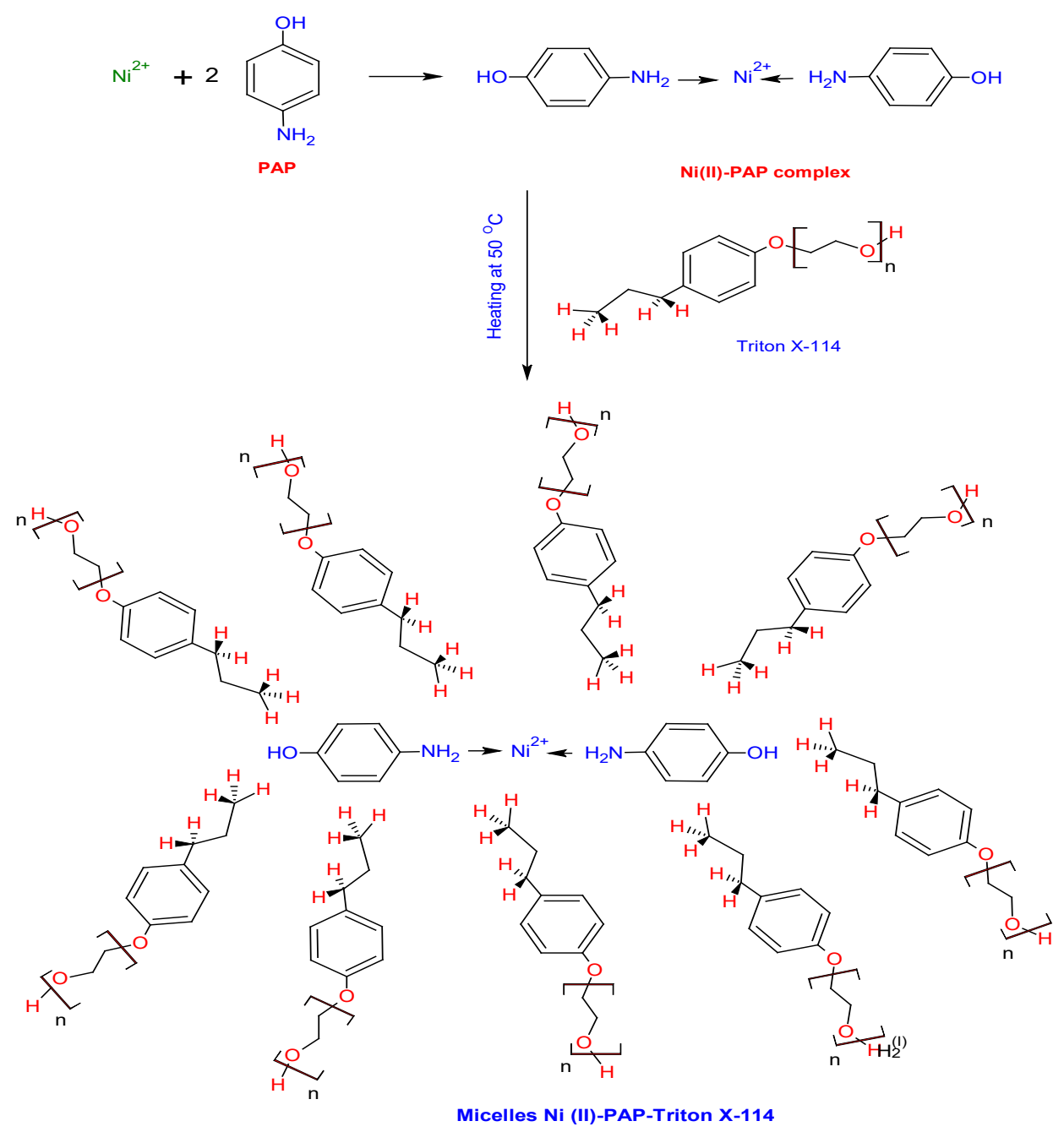

Fig 1. Schematic diagram for proposed mechanism of Ni(II)-PAP complex separation via the CPE method [22]

diluted to $10 \mathrm{~mL}$ using deionized water then placed in the super mixer to mix the solution. After this, the mixture was held in a water bath at $50{ }^{\circ} \mathrm{C}$ for $10 \mathrm{~min}$. The separation into two phases was achieved by centrifugation for $5 \mathrm{~min}$. at $3500 \mathrm{rpm}$. The solution was then cooled in an ice bath at $(0-5){ }^{\circ} \mathrm{C}$ for $5 \mathrm{~min}$ to increase the viscosity so that the surfactant-rich phase separated easily by converting tube. The surfactant-rich phase of this procedure was dissolved and diluted to $0.75 \mathrm{~mL}$ with absolute ethanol and transferred into $1.0 \mathrm{~cm}$ quartz cell $(1$ $\mathrm{mL})$. The absorbance of the solution was measured at $\lambda_{\max }$ $=629 \mathrm{~nm}$ against a blank solution prepared in the same manner. Fig. 1 shows the CPE scheme and the proposed reaction mechanism for the nickel(II)-PAP complex.

\section{Absorption Spectra}

Fig. 2 shows the absorbance spectrum for the PAP reagent, standard solution of nickel(II) and the nickel(II)-PAP complex with a surfactant-rich phase against a reagent blank prepared under similar conditions. The absorbance spectrum of PAP were at $409 \mathrm{~nm}$, the absorbance spectra of standard solution of nickel(II) were at $302 \mathrm{~nm}$, while the absorbance spectra of the Ni(II)-PAP complex was at $629 \mathrm{~nm}$.

\section{- RESULTS AND DISCUSSION}

\section{Optimization of the Experimental Conditions}

To achieve the best performance for the cloud point extraction procedure, effects including order of 

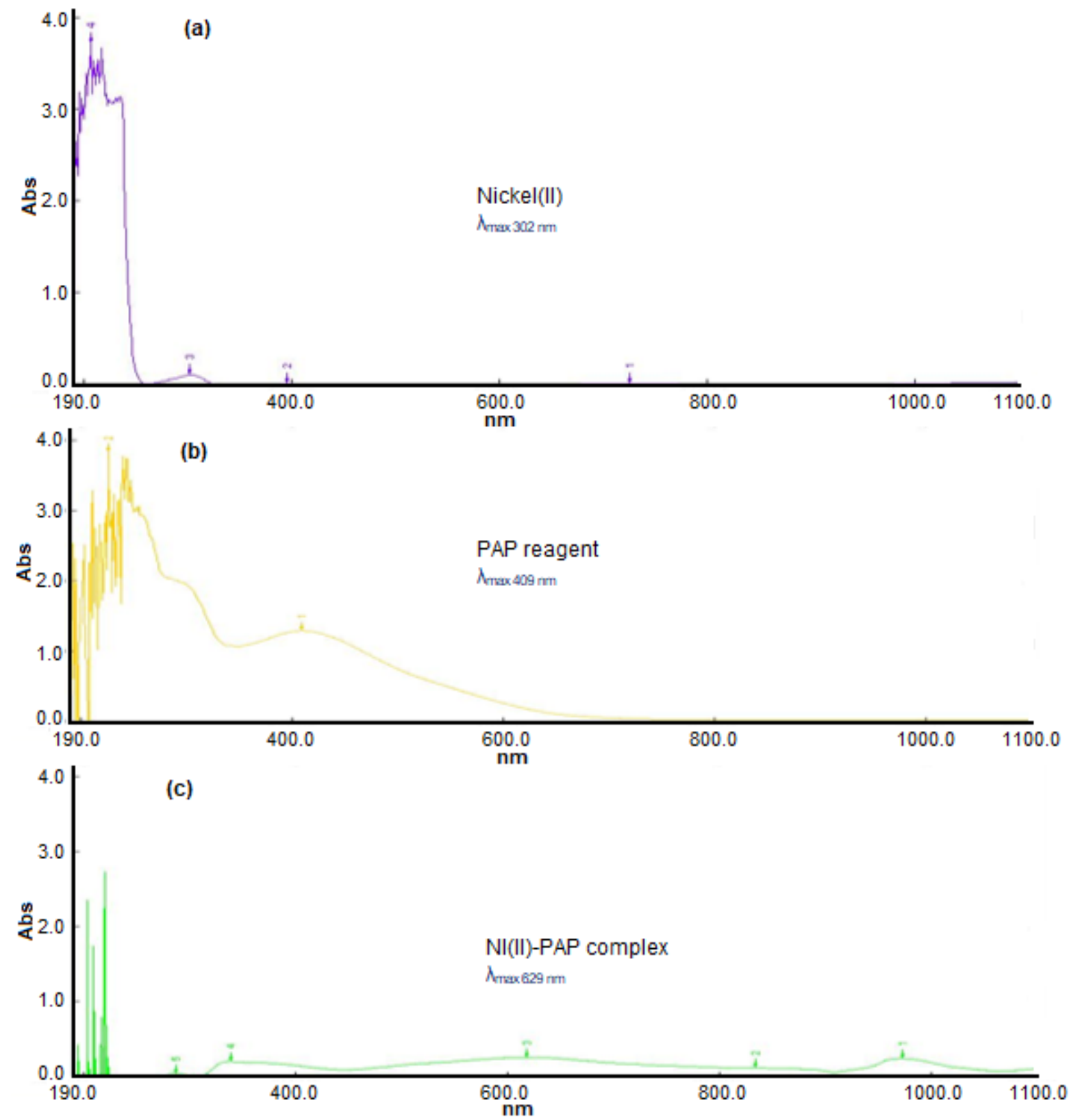

Fig 2. Absorption spectra for (a) Ni(II) metal solution, (b) Para-aminophenol (PAP) reagent, and (c) Ni(II)-PAP complex

addition, $\mathrm{pH}$, concentration of reagent, types of surfactant, concentration of surfactant, equilibrium temperature, time of incubation, salt out and interfering ions were evaluated and optimized.

\section{Order of addition effect}

The most important factors that have been studied are the order of additions where it was change the order of
Table 1. Effect of order addition on the absorbance of the result

\begin{tabular}{llll}
\hline Order addition & Ao & Aaq & As \\
\hline $\mathrm{M}+\mathrm{R}+\mathrm{T}$ & 0.000 & 0.000 & 1.215 \\
$\mathrm{R}+\mathrm{M}+\mathrm{T}$ & 0.000 & 0.000 & 1.158 \\
\hline Ao: Absorbance of an original solution \\
As:Absorbance of a rich phase surfactant \\
Aaq: Absorbance of an aqueous
\end{tabular}




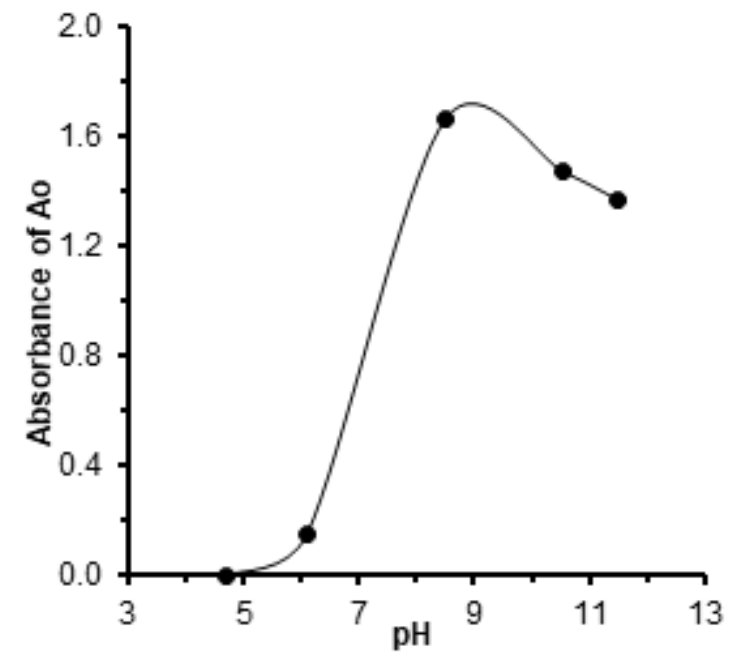

Fig 3. The effects of $\mathrm{pH}$ on the absorbance of $\mathrm{Ni}(\mathrm{II})$-PAP complex

Table 2. Effect of concentration of PAP on the signal output

\begin{tabular}{ccccc}
\hline $\begin{array}{c}\text { Volume } \\
\text { added }(\mathrm{mL})\end{array}$ & $\begin{array}{c}\text { PAP concentration } \\
\text { mmol. } \mathrm{L}^{-1}\end{array}$ & Ao & Aaq & As \\
\hline 1.00 & 0.00796 & 0.394 & 0.136 & 1.579 \\
0.50 & 0.00416 & 0.286 & 0.042 & 1.560 \\
0.25 & 0.00254 & 0.244 & 0.034 & 1.329 \\
0.10 & 0.00086 & 0.111 & 0.000 & 0.986 \\
0.05 & 0.00043 & 0.000 & 0.000 & 0.355 \\
0.03 & 0.00026 & 0.000 & 0.000 & 0.192 \\
\hline
\end{tabular}

Table 3. Type of surfactant effect on the absorbance of $\mathrm{Ni}(\mathrm{II})$-PAP

\begin{tabular}{lccc}
\hline Type of surfactant & Ao & Aaq & As \\
\hline SDS & 0.377 & 0.476 & 0.475 \\
Triton-X100 & 0.377 & 0.286 & 1.011 \\
Triton-X114 & 0.377 & 0.115 & 1.751 \\
\hline
\end{tabular}

( $0.5 \mathrm{ppm} / 10 \mathrm{~mL})$ of the $\mathrm{Ni}(\mathrm{II})$ and $(0.0916 \mathrm{M} / 0.25 \mathrm{~mL})$ of the reagent (PAP) as shown through the results in Table 1 that produced the greatest absorbance value from the first test.

\section{Effect of $\mathrm{pH}$}

The formation of metal complexes and their chemical stabilities are two important influencing factorsin cloud point extraction. The $\mathrm{pH}$ plays a critical role on metallic complex formation and subsequent extraction and has found to be a significant parameter for

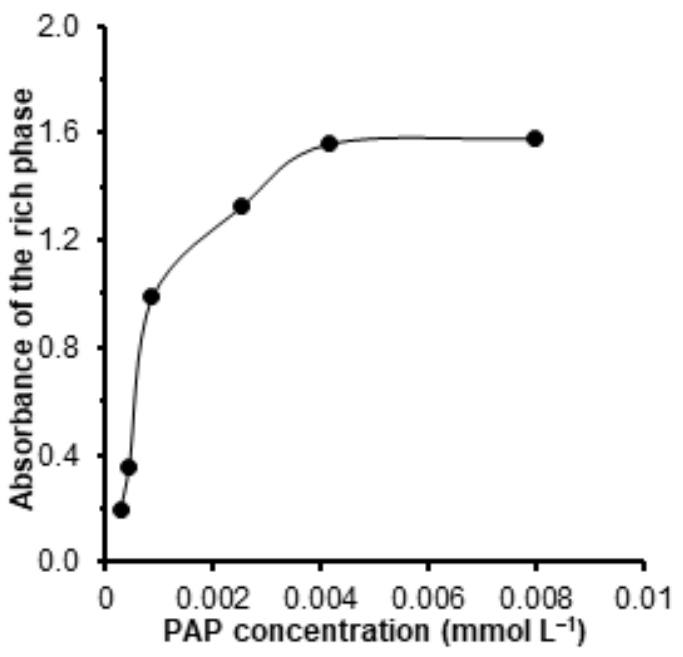

Fig 4. Effect of amount of PAP on the absorbance of the produced complex

$\mathrm{CPE}$. The $\mathrm{pH}$ of the sample solution was adjusted to lie in the range (4.7-11.5) using $0.1 \mathrm{M} \mathrm{NaOH}$ and $0.1 \mathrm{M}$ $\mathrm{HCl}$ solution using a $\mathrm{pH}$ meter. The result in Fig. 3 shows an increase of absorbance when the $\mathrm{pH}$ was equal to 8.5 , the complexation reaction at $\mathrm{pH}$ values lower than 8.5 is incomplete, probably due to the protonation of PAP; on the other hand, at $\mathrm{pH}$ values greater than 8.5 hydrolysis of $\mathrm{Ni}(\mathrm{II})$ occurs.

\section{Reagent concentration effect}

The concentration effect of chelating agent paraamino phenol (PAP) on absorbance value was studied by using various volumes from $(0.01-1.00) \mathrm{mL}$ of $1 \% \mathrm{w} / \mathrm{v}$ PAP, whilst keeping other factors constant. The results in Table 2 and Fig. 4 show that the absorbance value increased with increasing amounts of reagent (PAP). The best results relied upon when the amount of reagent is $0.25 \mathrm{~mL}$, while other results and that's were neglected for many reasons, including Precipitates be when added large quantities of reagent PAP.

\section{Influence of type of surfactant}

The efficiency of the cloud point extraction is dependent on the type of surfactant used. In this study, this was examined using certain concentrations of various types of surfactant such as Triton X-100, Triton $\mathrm{X}-114$, or sodium dodecyl sulphate (SDS). The results in Table 3 and Fig. 5 show that the absorbance value increased with Triton X-114. 


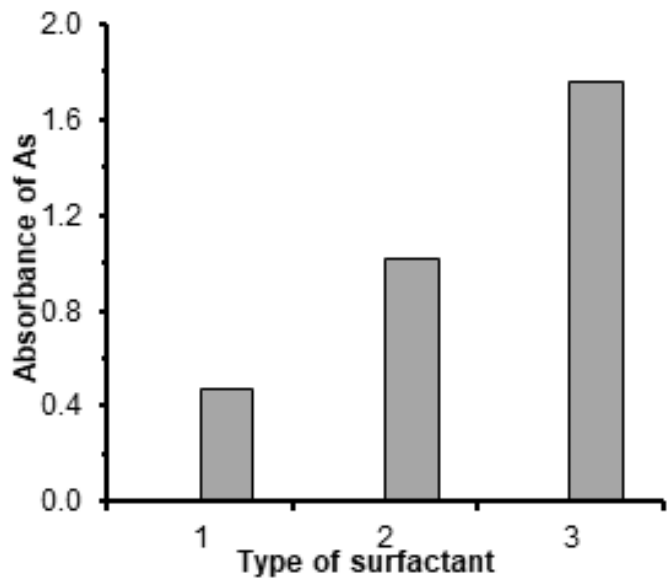

Fig 5. Effects of types of surfactant in the rich phase formation: (1) SDS, (2) Triton X-100 and (3) Triton X114

Table 4. Amount of Triton X-114 effect on the rich phase formation

\begin{tabular}{cccc}
\hline $\begin{array}{c}\text { Volume added of } \\
\text { Triton X-114 mL }\end{array}$ & Ao & Aaq & As \\
\hline 1.00 & 0.130 & 0.000 & 1.118 \\
0.75 & 0.145 & 0.000 & 1.190 \\
0.50 & 0.122 & 0.000 & 1.716 \\
0.25 & 0.131 & 0.000 & 1.689 \\
0.10 & 0.112 & 0.000 & 1.680 \\
0.05 & 0.122 & 0.000 & 1.614 \\
0.02 & 0.134 & 0.000 & 1.509 \\
\hline
\end{tabular}

\section{Amount of Triton X-114 effect}

The Triton X-114 is one of the non-ionic surfactants extensively used in CPE. This is due to its advantages such as commercial availability in high purity, relatively low cloud point temperature, low toxicity, low cost and high density of the surfactant-rich phase which facilitates phase separation by centrifugation. Table 4 tabulated the results of the effect of amount of non-ionic surfactant, the volume range of $20 \%(\mathrm{v} / \mathrm{v})$ of Triton X-114 from $0.02-$ $1.00 \mathrm{~mL}$. The absorbance of the complex increased by increasing the volume of Triton X-114 added.

\section{Effect of equilibrium temperature}

The cloud point extraction efficiency is strongly affected by temperature. The effect of the equilibrium temperature was examined due to its importance in driving the reaction to completion and the efficient

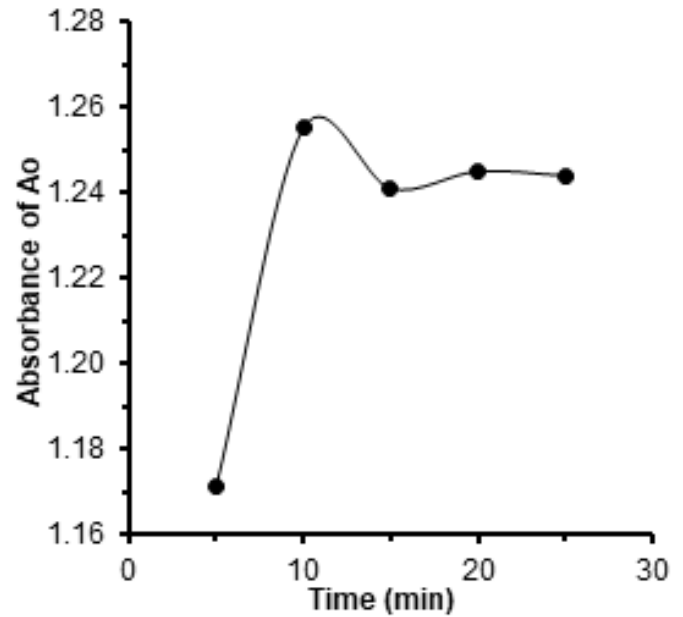

Fig 6. Effect of incubation time on the rich phase formation

Table 5. Effect of equilibrium temperature on the absorbance of the Ni(II)-PAP complex

\begin{tabular}{llll}
\hline Temperature ${ }^{\circ} \mathrm{C}$ & Ao & Aaq & As \\
\hline 50 & 0.123 & 0.000 & 1.477 \\
55 & 0.119 & 0.000 & 1.390 \\
60 & 0.122 & 0.000 & 1.226 \\
65 & 0.120 & 0.000 & 1.300 \\
70 & 0.132 & 0.000 & 1.079 \\
75 & 0.139 & 0.000 & 1.271 \\
80 & 0.125 & 0.000 & 1.252 \\
85 & 0.119 & 0.000 & 1.174 \\
\hline
\end{tabular}

separation of phases. The temperature of the water bath was varied from $(50-85){ }^{\circ} \mathrm{C}$. The results were listed in Table 5 that shows the highest absorbance signals when the temperature at $50{ }^{\circ} \mathrm{C}$.

\section{Incubation time effect}

In order to achieve easy phase separation and efficient pre-concentration in cloud point extraction processes, it was desirable to employ the shortest incubation time. The effect of incubation time was investigated over times ranging from (1-25) $\mathrm{min}$. The results demonstrate that an incubation time of $10 \mathrm{~min}$ was optimal as shown as in Fig. 6, and was thus chosen for further experiments.

\section{Salt out effect}

In the cloud point extraction, the addition of salt to the sample solution helps to achieve phase separation 
and increased mass transfer of the analyte from the aqueous phase to the surfactant-rich phase, the results listed in Table 6 . The effects of salts on CPE were studied by added $0.5 \mathrm{~mL}$ of $15 \% \mathrm{w} / \mathrm{v}$ of $\mathrm{NaCl}, \mathrm{KCl}, \mathrm{Na}_{2} \mathrm{CO}_{3}$ and $\mathrm{Na}_{2} \mathrm{SO}_{4}$ to the solution of $\mathrm{Ni}(\mathrm{II})$ and were subjected to the complete procedure. The results demonstrate that the presence some salts led to increasing the absorbance due to increasing CPE efficiency because of these salts water molecules will pull and destroy the hydration shell of nickel ion which leads to increase the bonding between the reagent (PAP) and nickel, where the $\mathrm{Na}_{2} \mathrm{CO}_{3}$ salt is the best to increase the sensitivity of the method.

\section{Effect of interferences}

The effects of foreign ions on the extraction of $2 \mathrm{mg} . \mathrm{L}^{-1}$ of $\mathrm{Ni}$ (II) were studied, including cations that may react with PAP or species that may react with analyte and decrease the extraction efficiency to perform this study. To this end, $100 \mathrm{mg} . \mathrm{L}^{-1}$ of 'interfering' ions was added to a solution of $2 \mathrm{ppm} \mathrm{Ni(II)} \mathrm{and} \mathrm{was} \mathrm{subjected} \mathrm{to}$ an identical procedure. The results demonstrate that the presence of large amounts of the species commonly present in water samples have a significant effect on the cloud point extraction efficiency. Table 7 tabulated the results of interferences effect, from that can be seen some ions interfering with nickel ion like $\mathrm{Cr}$ (III) and $\mathrm{Al}(\mathrm{III})$

Table 6. Effect of salts out on the absorbance of Ni(II)PAP

\begin{tabular}{lc}
\hline Type of salts & As \\
\hline $\mathrm{NaCl}$ & 1.025 \\
$\mathrm{KCl}$ & 1.122 \\
$\mathrm{Na}_{2} \mathrm{CO}_{3}$ & 2.575 \\
$\mathrm{Na}_{2} \mathrm{SO}_{4}$ & 1.296 \\
without salt & 0.932 \\
\hline
\end{tabular}

Table 7. Effect of interference on the absorbance of Ni(II)-PAP

\begin{tabular}{llcc}
\hline Interfering ion & Added as & $\begin{array}{c}\text { Conc. of Interfering ion } \\
\text { ppm/Conc. of } \mathrm{Cu}(\mathrm{II}) \mathrm{mg} . \mathrm{L}^{-1} \text { ratio }\end{array}$ & Abs. \\
\hline $\mathrm{Co}(\mathrm{II})$ & $\mathrm{Co}\left(\mathrm{NO}_{3}\right)_{2}$ & 50 & 1.762 \\
$\mathrm{Fe}(\mathrm{III})$ & $\mathrm{FeCl}_{3}$ & 50 & 0.632 \\
$\mathrm{Cu}(\mathrm{II})$ & $\mathrm{Cu}\left(\mathrm{NO}_{3}\right)_{2} \cdot 3 \mathrm{H}_{2} \mathrm{O}$ & 50 & 1.381 \\
$\mathrm{Cr}(\mathrm{III})$ & $\mathrm{Cr}\left(\mathrm{NO}_{3}\right)_{3}$ & 50 & 0.712 \\
$\mathrm{Al}(\mathrm{III})$ & $\mathrm{Al}\left(\mathrm{NO}_{3}\right)_{3} \cdot 9 \mathrm{H}_{2} \mathrm{O}$ & 50 & 0.494 \\
$\mathrm{~Pb}(\mathrm{II})$ & $\mathrm{Pb}\left(\mathrm{NO}_{3}\right)_{2}$ & 50 & 1.068 \\
$\mathrm{Zn}(\mathrm{II})$ & $\mathrm{ZnCl}_{2}$ & 50 & 1.244 \\
without & --- & --- & 1.477 \\
\hline
\end{tabular}

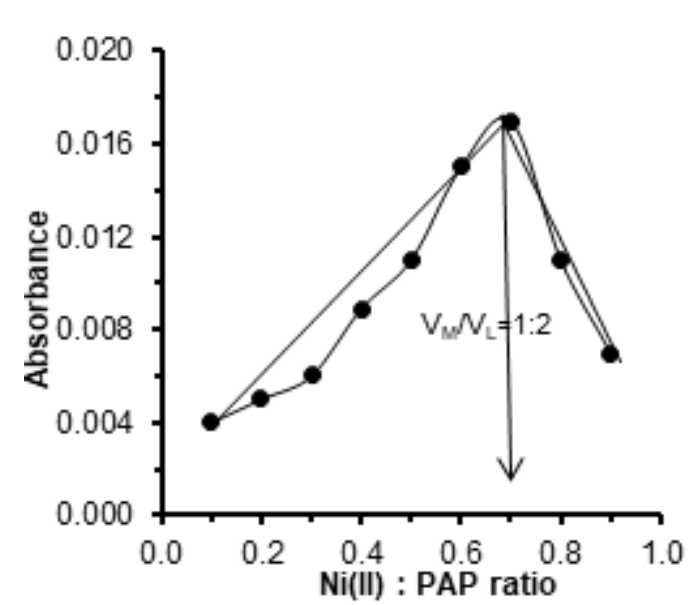

Fig 7. Job's plot of absorbance at $629 \mathrm{~nm}$ versus mole fraction of $\mathrm{Ni}(\mathrm{II})$ ion

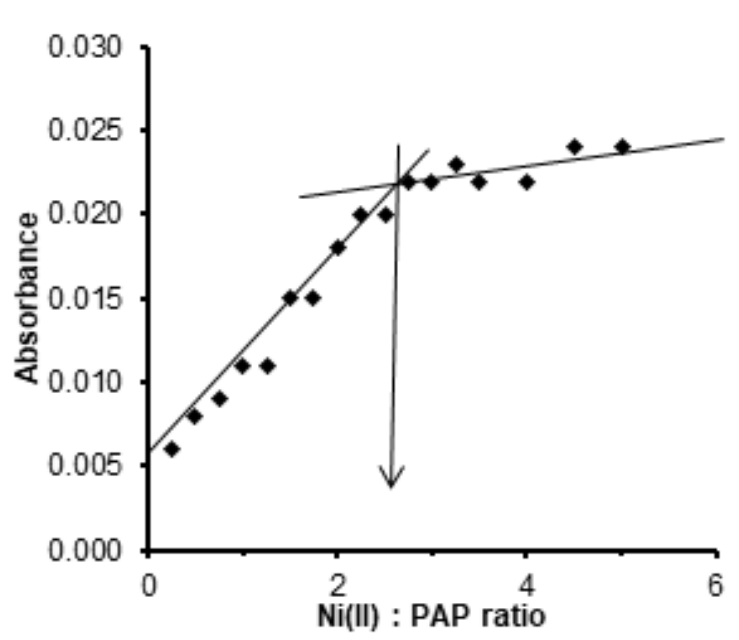

Fig 8. Mole ratio plots of the PAP-Ni(II) complex 
Table 8. Summary of results for calibration graph for Ni (II) by using UV-Vis - CPE

\begin{tabular}{ccccc}
\hline $\begin{array}{c}\text { Conc. of Ni(II) } \\
\mu \mathrm{g} . \mathrm{mL}^{-1}\end{array}$ & $\begin{array}{c}\text { Mean } \\
\overline{\mathrm{y}}\end{array}$ & $\begin{array}{c}\mathrm{SD} \\
\sigma_{\mathrm{n}-1}\end{array}$ & $\mathrm{RSD} \%$ & $\begin{array}{c}\text { C.I } \\
\overline{\mathrm{y}} \pm \mathrm{t}_{0.05 / 2} \frac{\boldsymbol{\sigma}_{\boldsymbol{n}-1}}{\sqrt{n}}\end{array}$ \\
\hline 10 & 2.310 & 0.0070 & 0.003030 & $2.310 \pm 0.017$ \\
8 & 2.300 & 0.0050 & 0.002187 & $2.300 \pm 0.013$ \\
6 & 2.156 & 0.1360 & 0.063106 & $2.156 \pm 0.338$ \\
4 & 1.598 & 0.0080 & 0.005056 & $1.598 \pm 0.020$ \\
2 & 1.307 & 0.0210 & 0.016174 & $1.307 \pm 0.052$ \\
1 & 0.605 & 0.1209 & 0.179942 & $0.605 \pm 0.300$ \\
0.5 & 0.517 & 0.1082 & 0.209389 & $0.517 \pm 0.269$ \\
0.25 & 0.497 & 0.0040 & 0.007762 & $0.497 \pm 0.010$ \\
0.1 & 0.387 & 0.0310 & 0.080103 & $0.387 \pm 0.077$ \\
0.08 & 0.326 & 0.0470 & 0.144051 & $0.326 \pm 0.117$ \\
0.05 & 0.264 & 0.0262 & 0.099355 & $0.264 \pm 0.065$ \\
0.01 & 0.146 & 0.0255 & 0.174271 & $0.146 \pm 0.063$ \\
0.005 & 0.076 & 0.0236 & 0.308205 & $0.076 \pm 0.059$ \\
\hline
\end{tabular}

Table 9. Results for linear regression analysis of nickel(II) using CPE

\begin{tabular}{lccccc}
\hline & $\begin{array}{c}\text { Range of conc. } \\
\mu \mathrm{g} \cdot \mathrm{mL}^{-1}\end{array}$ & $\begin{array}{c}\text { Linear regression } \\
\text { equation }\end{array}$ & $\begin{array}{c}\mathrm{R} \\
\mathrm{r}^{2}\end{array}$ & $\begin{array}{c}\mathrm{t}_{\text {critical }} \text { at 95\% } \\
\text { confidence level, } \mathrm{n}-\end{array}$ & $\begin{array}{c}\text { Calculated t-value } \\
\mathrm{r}^{2} \%\end{array}$ \\
\hline $\mathrm{Ni}(\mathrm{II})$ & & & 2 & $\mathrm{t}_{\text {cal }}=(|\mathrm{r}| \sqrt{\mathrm{n}}-2) / \sqrt{\left(1-\mathrm{r}^{2}\right)}$ \\
$\mathrm{n}=12$ & $0.005-10.000$ & $\mathrm{Y}=0.3001 \mathrm{X}+0.0927$ & 0.9682 & $2.228<<<7.8977$ \\
& & & 96.82 & \\
\hline
\end{tabular}

ion but the unnecessary effect because the concentration of these ions is very low in urine samples In comparison with the concentration of $\mathrm{Ni}$ (II) ion.

\section{Stoichiometry of the Complex}

The stoichiometry of a complex can be determined by using either of two methods. In Job's method (Fig. 7), a solution of reagent (PAP) and nickel(II) ion $\left(1 \times 10^{-3} \mathrm{M}\right)$ were prepared and mixed in continuous variation then diluted to $10 \mathrm{~mL}$ of DDW after this measurement the solution by UV-Vis Spectrophotometer at $629 \mathrm{~nm}$. The stoichiometry of the complex determined by Job's method was found to be $1: 2$ ratio of $\mathrm{M} ; \mathrm{L}$.

In the mole ratio method (Fig. 8), a solution of reagent (PAP) and nickel(II) ion $\left(1 \times 10^{-3} \mathrm{M}\right)$ were prepared. There are two ways that can be followed in order to determine the mole ratio, namely when the concentration of nickel(II) ion is fixed and the volume of reagent (PAP) is changed, or vice versa, then diluted to $10 \mathrm{~mL}$ of deionized water after this measurement the solution by UV-Vis Spectrophotometer at $629 \mathrm{~nm}$. The stoichiometry of the complex, as determined by the mole ratio method, was found to be 1: 2 as M:L ratio.

\section{Calibration Curve of Complexes by Coupling the UV-Vis Method with CPE}

A calibration curve (Fig. 9) of absorbance versus concentration was constructed by collecting the analytical signals of different concentrations of $\mathrm{Ni}(\mathrm{II})$ standard solutions. Under the optimum experimental conditions, the calibration curve for $\mathrm{Ni}(\mathrm{II})$ ion is linear from (0.005-0.1) mg. $\mathrm{mL}^{-1}$ with a correlation coefficient (R) of 0.9682 . Table 8 shows the summary of results for calibration graph while Table 9 listed the results for linear regression analysis of nickel(II) using CPE.

\section{Precision and Accuracy}

\section{Repeatability}

The test of the precision of the UV-Vis-CPE method for nickel(II) ion determination can be shown by 
calculating the relative standard deviation (RSD\%) values for the resulting repeatability test. Concentrations of $(0.25$ and 2.0) $\mu \mathrm{g} \cdot \mathrm{mL}^{-1}$ of $\mathrm{Ni}(\mathrm{II})$ were used. The relative standard deviations (RSD\%) determined for the $\mathrm{Ni}(\mathrm{II})$ ion are tabulated in Table 10. A percentage relative standard deviation of less than $5 \%$ can be an achieved using this method.

\section{Calibration curve of Ni(II) by FAAS}

A series of standard nickel(II) solutions ranging from 0 to $4 \mu \mathrm{g}$. $\mathrm{mL}^{-1}$ were recorded using $\lambda_{\max } 232.0 \mathrm{~nm}$ to determine an appropriate calibration curve for $\mathrm{Ni}(\mathrm{II})$ using the FAAS technique.

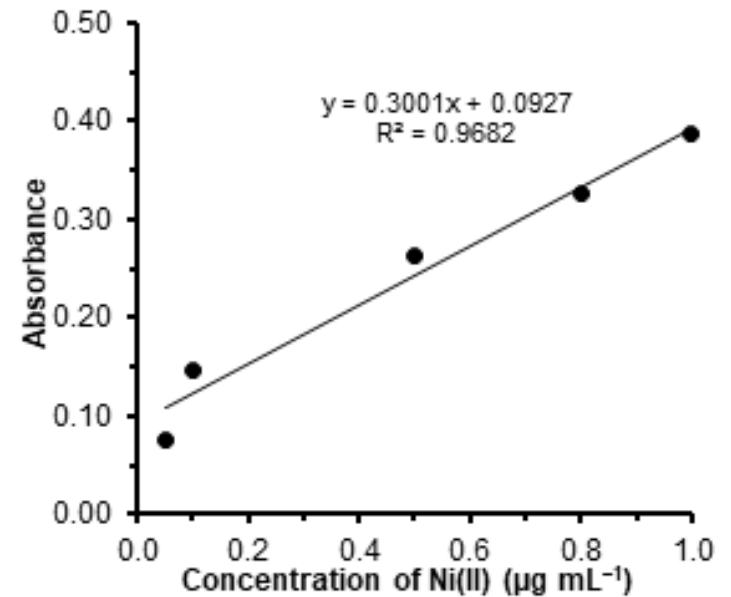

Fig 9. Calibration curve for $\mathrm{Ni}(\mathrm{II})-\mathrm{PAP}$ complex

Table 10. Repeatability of Ni(II) complex at optimum parameters

\begin{tabular}{|c|c|c|c|c|}
\hline $\begin{array}{c}\text { No. of } \\
\text { repeating }\end{array}$ & $\begin{array}{c}\text { Conc. of } \mathrm{Ni}(\mathrm{II}) \\
\left(\mu \mathrm{g} \cdot \mathrm{mL}^{-1}\right)\end{array}$ & Abs. & Mean \pm SD & RSD\% \\
\hline 6 & 0.25 & $\begin{array}{l}0.525,0.520 \\
0.520,0.517 \\
0.499,0.476\end{array}$ & $0.5095 \pm 0.01870$ & 3.67 \\
\hline 6 & 2 & $\begin{array}{l}1.322,1.299 \\
1.280,1.290 \\
1.300,1.299\end{array}$ & $1.2983 \pm 0.01392$ & 1.07 \\
\hline
\end{tabular}

Table 11. Results of cloud point determination of nickel (II) concentrations in urine samples by coupling with the UVVis spectrophotometry and AAS techniques

\begin{tabular}{llccl}
\hline Occupation & Method & No. of sample & \multicolumn{1}{c}{ Mean \pm SD } & C.I $_{0.05 / 2} \frac{\sigma_{n-1}}{\sqrt{n}}$ \\
\hline \multirow{2}{*}{ Oil refineries } & UV-Vis-CPE & 14 & $0.01689 \pm 0.00637$ & 0.003670 \\
& AAS-CPE & 16 & $0.02327 \pm 0.01679$ & 0.008946 \\
\cline { 2 - 5 } Welding & UV-Vis-CPE & 10 & $0.01795 \pm 0.00947$ & 0.006770 \\
& AAS-CPE & 11 & $0.01491 \pm 0.00836$ & 0.005622 \\
\cline { 2 - 5 } Casting alloys & UV-Vis-CPE & 5 & $0.01393 \pm 0.00156$ & 0.001930 \\
\multirow{2}{*}{ Terminals to } & AAS-CPE & 5 & $0.00742 \pm 0.00452$ & 0.005623 \\
\cline { 2 - 5 } provide fuel & UV-Vis-CPE & 3 & $0.02243 \pm 0.00325$ & 0.008000 \\
\multirow{2}{*}{ Dyeing } & AAS-CPE & 5 & $0.044710 \pm 0.03100$ & 0.049600 \\
\cline { 2 - 5 } & UV-Vis-CPE & 5 & $0.01856 \pm 0.01240$ & 0.015400 \\
\multirow{2}{*}{ Total } & AAS-CPE & 5 & $0.01217 \pm 0.0045$ & 0.005638 \\
\cline { 2 - 5 } & UV-Vis-CPE & 37 & $0.01745 \pm 0.00770$ & 0.002100 \\
\hline & Direct AAS & 42 & $0.020425 \pm 0.01981$ & 0.006170 \\
\hline
\end{tabular}

Table 12. Results of Grubbs-test applied on the Ni(II) ions concentration results

\begin{tabular}{|c|c|c|c|c|}
\hline No. of & Readi & uded & & Range of concentration $\mu \mathrm{g} \cdot \mathrm{mL}^{-1}$ \\
\hline $\begin{array}{l}\frac{\text { sample }}{\mathrm{Ni}(\mathrm{II})} 44 \\
\end{array}$ & $\begin{array}{l}\text { UV-Vis-CPE } \\
1\end{array}$ & $\frac{\text { FAAS-CPE }}{1}$ & C.F & $\begin{array}{l}\text { FAAS-CPE } \\
0.0020-0.1097\end{array}$ \\
\hline
\end{tabular}




\section{Application of method UV-Vis and AAS}

These methods were applied successfully to determine the $\mathrm{Ni}(\mathrm{II})$ ion in urine samples after pre-concentration by cloud point extraction with different concentration are tabulated in Table 11; also, from the results presented in Fig. 10, the concentration of $\mathrm{Ni}(\mathrm{II})$ can be seen.

\section{Statistical treatment of data results}

The results of the application of the Grubbs test to the outliers of the 44 sample concentrations after estimation by UV-Vis spectrophotometry and FAAS techniques, gave the excluded values shown in Table 12 . When excluding such outliers, the significance tests described so far are used for comparing means and hence for detecting systematic errors. The F-test was used to compare the variances between the concentrations of copper

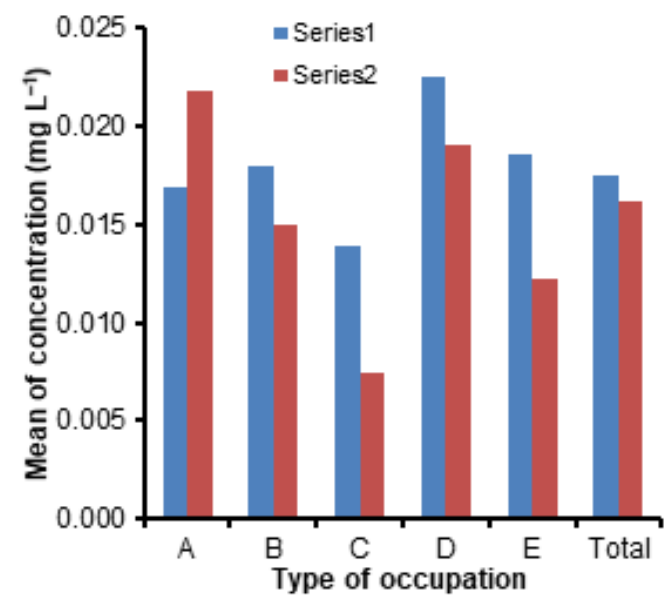

Fig 10. The nickel(II) concentration in urine samples by occupation as determined via UV-Vis-CPE (series 1) and FAAS-CPE (series 2). A: Oil refineries, B: Welding, C: Casting alloys, D: Terminals providing fuels, E: Dyeing

Table 13. Application F-test on the Ni(II) concentration in samples to compare between the results given by the two methods (UV-Vis-CPE and AAS-CPE)

\begin{tabular}{|c|c|c|c|c|c|c|c|}
\hline Occupation & $\begin{array}{c}\text { Type of } \\
\text { measurement }\end{array}$ & d.f $=n-1$ & $\begin{array}{l}\mathrm{SD} \\
\mathrm{n}-1\end{array}$ & $\begin{array}{c}\text { Variance } \\
\sigma^{2}\end{array}$ & $\begin{array}{c}\text { F-calculate; } \\
\mathrm{F}=\sigma_{2}^{2} / \sigma_{1}^{2} ; \sigma_{2}^{2}>\sigma_{1}^{2}\end{array}$ & $\begin{array}{c}\text { F-critical } \\
\text { value }\end{array}$ & $\mathrm{P}$-value \\
\hline Oil refineries & $\begin{array}{l}\text { UV-Vis-CPE } \\
\text { AAS-CPE }\end{array}$ & $\begin{array}{l}13 \\
15\end{array}$ & $\begin{array}{l}0.0063 \\
0.0167\end{array}$ & $\begin{array}{l}0.07937 \\
0.35948\end{array}$ & 4.5292 & 2.4481 & 0.0033 \\
\hline Welding & $\begin{array}{l}\text { UV-Vis-CPE } \\
\text { AAS-CPE }\end{array}$ & $\begin{array}{c}9 \\
10\end{array}$ & $\begin{array}{l}0.0094 \\
0.0083\end{array}$ & $\begin{array}{l}0.09695 \\
0.30183\end{array}$ & 3.1149 & 3.0203 & 0.0456 \\
\hline Casting alloys & $\begin{array}{l}\text { UV-Vis-CPE } \\
\text { AAS-CPE }\end{array}$ & $\begin{array}{l}4 \\
4\end{array}$ & $\begin{array}{l}0.0015 \\
0.0045\end{array}$ & $\begin{array}{l}0.03872 \\
0.06708\end{array}$ & 1.7324 & 6.3882 & 0.3037 \\
\hline $\begin{array}{l}\text { Terminals to } \\
\text { provide fuel }\end{array}$ & $\begin{array}{l}\text { UV-Vis-CPE } \\
\text { AAS-CPE }\end{array}$ & $\begin{array}{l}2 \\
4\end{array}$ & $\begin{array}{l}0.0032 \\
0.0399\end{array}$ & $\begin{array}{l}0.05656 \\
0.19974\end{array}$ & 3.5316 & 6.9442 & 0.1307 \\
\hline Dyeing & $\begin{array}{l}\text { UV-Vis-CPE } \\
\text { AAS-CPE }\end{array}$ & $\begin{array}{l}4 \\
4 \\
\end{array}$ & $\begin{array}{l}0.0124 \\
0.0045\end{array}$ & $\begin{array}{l}0.11135 \\
0.06708\end{array}$ & 1.6599 & 6.3882 & 0.3177 \\
\hline Total & UV-Vis-CPE & $\begin{array}{l}36 \\
41 \\
\end{array}$ & $\begin{array}{l}0.0077 \\
0.0198 \\
\end{array}$ & $\begin{array}{l}0.08774 \\
0.14071 \\
\end{array}$ & 1.6037 & 1.7032 & 0.0720 \\
\hline
\end{tabular}

$\mathrm{P}$-value $<0.05$ sig. difference, $\mathrm{P}$-value $>0.05$ non-significant difference

Table 14. The results of t-test (one tail) to compare with the concentration of $\mathrm{Ni}$ (II) in urine samples with the literature values

\begin{tabular}{lllrl}
\hline Occupation & Method & d.f; $\mathrm{n}-1$ & $\mathrm{t}$-calculated; $\mathrm{t}=\overline{\mathrm{y}}-\mu \frac{\sqrt{n}}{\sigma_{n-1}}$ & P-Value \\
\hline \multirow{2}{*}{ Oil refineries } & UV-Vis-CPE & 13 & 8.9680 & 0.00001 \\
& FAAS-CPE & 15 & 5.1220 & 0.00006 \\
\cline { 2 - 5 } Welding & UV-Vis-CPE & 9 & 5.4095 & 0.00021 \\
& FAAS-CPE & 10 & 5.2367 & 0.00019 \\
\cline { 2 - 5 } Casting alloys & UV-Vis-CPE & 4 & 17.5300 & 0.00003 \\
Terminals to & FAAS-CPE & 4 & 2.8323 & 0.02361 \\
nyovide fuel & UV-Vis-CPE & 2 & 11.2040 & 0.00393 \\
Dyeing & FAAS-CPE & 4 & 2.4090 & 0.03681 \\
\cline { 2 - 5 } Total & UV-Vis-CPE & 4 & 3.0403 & 0.01919 \\
& FAAS-CPE & 4 & 5.1678 & 0.00333 \\
\hline & UV-Vis-CPE & 36 & 12.4420 & 0.000001 \\
\hline
\end{tabular}


using the UV-Vis-CPE and FAAS-CPE methods to determine any significance or otherwise between them. Table 13 shows the results of the F-test. A comparison of the sample mean with the true mean must be based on Student's t-test to allow comparison of the mean nickel concentrations found by UV-Vis-CPE and FAAS-CPE. Table 14 shows the results of the t-test.

\section{- CONCLUSION}

Her, a simple, a successful and inexpensive preconcentration method to determine $\mathrm{Ni}(\mathrm{II})$ ion in urine samples that depended on the cloud point extraction method which is deals with very small quantity of urine sample, while the concentration factor (C.F) is more than 50 , so that increase of the sensitivity of measurement by UV-Vis spectrophotometry and Flame Atomic Absorption Spectrometry Technique.

\section{- REFERENCES}

[1] Saravanabhavan, G., Werry, K., Walker, M., Haines, D., Malowany, M., and Khoury, C., 2017, Human biomonitoring reference values for metals and trace elements in blood and urine derived from the Canadian Health Measures Survey 2007-2013, Int. J. Hyg. Environ. Health, 220, 189-200.

[2] Mohammedi, S.Z., Afzali, D., and Baghelani, Y.M., 2010, Flame atomic absorption spectrometry determination of trace amounts of nickel ions in water samples after ligandless ultrasound-assisted emulsification microextraction, Anal. Sci., 26 (9), 973-977.

[3] Sabermahani, F., Saeidi, M., and Sharifzade, V., 2013, Removal of nickel(II) and palladium(II) from surface waters, Bull. Chem. Soc. Ethiop., 27 (1), 15-23.

[4] Muyssen, B.T.A., Brix, K.V., DeForest, D.K., and Janssen, C.R., 2004, Nickel essentiality and homeostasis in aquatic organisms, Environ. Rev., 12 (2), 113-129.

[5] Rodushkin, I., and Ödman, F., 2001, Application of inductively coupled plasma sector field mass spectrometry for elemental analysis of urine, J. Trace Elem. Med. Biol., 14 (4), 241-247.
[6] Nekouel, F., and Nekouel, S., 2014, Determination of copper, nickel and cobalt in water and food samples by FAAS after separation and preconcentration using multi walled carbon nanotubes modified by methyl-(2-pyridyl) ketone oxime, Indian J. Sci. Res., 8 (1), 138-145.

[7] Efeçınar, M., and Şatıroğlu, N., 2013, Cloud point extraction for preconcentration of $\mathrm{Pb}$ (II), $\mathrm{Fe}(\mathrm{III})$, Cr(III) and determination by flame atomic absorption spectrometry, Hacettepe J. Biol. Chem., 41 (4), 321-330.

[8] Shemirani, F., Jamali, M.R., Kozani, R.R., and Salavati-Niasari, M., 2013, Cloud point extraction and preconcentration for the determination of $\mathrm{Cu}$ and $\mathrm{Ni}$ in natural water by flame atomic absorption spectrometry, Sep. Sci. Technol., 41 (13), 3065-3077.

[9] Ghaedi, M., Shokrollahi, A., Niknam, K., and Soylak, M., 2014, Cloud point extraction of copper, zinc, iron and nickel in biological and environmental samples by flame atomic absorption spectrometry, Sep. Sci. Technol., 44 (3), 773-786.

[10] Ghaedi, M., Shokrollahi, M., Ahmadi, F., Rajabi, H.R., and Soylak, M., 2008, Cloud point extraction for the determination of copper, nickel and cobalt ions in environmental samples by flame atomic absorption spectrometry, J. Hazard. Mater., 150 (3), 533-540.

[11] Peng, G., He, Q., Zhou, G., Li, Y., Su, X., Liu, M., and Fan, L., 2015, Determination of heavy metals in water samples using dual-cloud point extraction coupled with inductively coupled plasma mass spectrometry, Anal. Methods, 7 (16), 6732-6739.

[12] Brodzka, R., Trzcinka-Ochocka, M., and Janasik, B., 2013, Multi-element analysis of urine using dynamic reaction cell inductively coupled plasma mass spectrometry (ICP-DRC-MS) - A practical application, Int. J. Occup. Med. Environ. Health, 26 (2), 302-312.

[13] Milne, A., Landing, W., Bizimis, M.,, and Morton, P., 2010, Determination of $\mathrm{Mn}, \mathrm{Fe}, \mathrm{Co}, \mathrm{Ni}, \mathrm{Cu}, \mathrm{Zn}$, $\mathrm{Cd}$ and $\mathrm{Pb}$ in seawater using high resolution magnetic sector inductively coupled mass 
spectrometry (HR-ICP-MS), Anal. Chim. Acta, 665 (2), 200-207.

[14] Shah, S.M., Wang, H.N., and Su, X., 2011, Determination of trace amounts of nickel(II) by graphite furnace atomic absorption spectrometry coupled with cloud point extraction, Chem. Res. Chin. Univ., 27 (3), 366-370.

[15] Safavi, A., Abdollahi, H., Nezhad, M.R.H., and Kamali, R., 2004, Cloud point extraction, preconcentration and simultaneous spectrophoto metric determination of nickel and cobalt in water samples, Spectrochim. Acta, Part A, 60 (12), 28972901.

[16] Afkami, A., and Bahram, M., 2006, Cloud point extraction simultaneous spectrophotometric determination of $\mathrm{Zn}(\mathrm{II}), \mathrm{Co}(\mathrm{II})$, and $\mathrm{Ni}$ (II) in water and urine samples by 1-(2-pyridylazo)2-naphthol using partial least squares regression, Microchim. Acta, 155 (3-4), 403-408.

[17] Bezerra, M.A., Bruns, R.E., and Ferreira, S.L.C., 2006, Statistical design-principal component analysis optimization of a multiple response procedure using cloud point extraction and simultaneous determination of metals by ICP OES, Anal. Chim. Acta, 580 (2), 251-257.

[18] Escaleira, L.A., Santelli, R.E., Oliveira, E.P., de Carvalho, M.F.B., and Bezerra, M.A., 2009, Preconcentration procedure for determining trace amounts of $\mathrm{Ni}, \mathrm{Cd}, \mathrm{Pb}$ and $\mathrm{Cu}$ in high-salinity waters after cloud-point extraction, Int. J. Environ. Anal. Chem., 89 (7), 515-527.

[19] Muslim, J.R., 2015, Cloud point extraction method for separation, extraction and spectrophotometric determination of $\mathrm{Zn}(\mathrm{II})$ and $\mathrm{Ni}$ (II) as chloro anion complex by use of crystal violet, J. Kufa Chem. Sci., 10 (1), 86-103.

[20] Stalikas, C.D., 2002, Micelle-mediated extraction as a tool for separation and preconcentration in metal analysis, TrAC, Trends Anal. Chem., 21 (5), 343-355.

[21] Salager, J.L., 2002, Surfactants Types and Uses, Firp Booklet, Universidad Delos Andes, Venezuela.

[22] Khudhair, A.F., and Hassan, M.K., 2017, Cloud point extraction and determination trace iron(III) in urine samples by spectrophotometry and flame atomic absorption spectrometry, Asian J. Chem., 29 (12), 2725-2733.

[23] Khudhair, A.F., Saeed, S.I., Abbas, S.K, and Mohsin, H.M., 2017, Analysis of strontium(II) ion by turbidimetric method using Schiff base derivative, Asian J. Chem., 29 (5), 1065-1068.

[24] Afkhami, A., Madrakian, T., and Siampour, H., 2006, Cloud point extraction spectrophotometric determination of trace quantities of bismuth in urine, J. Braz. Chem. Soc., 17 (4), 797-802.

[25] Amin, A.S., 2011, Cloud-point extraction and spectrophotometric determination of trace quantities of bismuth in environmental water and biological samples, Spectrosc. Lett., 44 (6), 424-431. 